\title{
A Case Series of Neonatal Supraventricular Tachycardia: A Review of Different Management and Clinical Outcomes
}

\section{Özgün Araştırma Research Article}

\author{
Yenidoğan Supraventriküler Taşikardi Vaka Serisi: Farklı \\ Tedavilerin ve Klinik Sonuçların Değerlendirilmesi
}

Bora Baysal $\oplus^{\oplus}$, Ayşe Şimşek $\odot$

\begin{abstract}
Objective: Neonatal arrhythmias are defined as abnormal heart rates in the neonatal period. They may occur as a result of various cardiovascular, systemic and metabolic problems. Supraventricular tachycardia (SVT) is the most common arrhythmia in neonates. We aimed to evaluate the treatments and side effects of medications used in SVT treatment.

Method: A retrospective chart review was performed on newborns who were hospitalized, and treated with the diagnosis of SVT during hospitalization in the neonatal intensive care unit (NICU) of Buca Obstetric, Gynecology and Pediatrics Hospital in Izmir, Turkey from December 2016 to December 2017.

Results: Ten patients received the diagnosis of SVT. As for underlying diseases, $80 \%$ of the patients were evaluated as nonspecific SVT, while $20 \%$ of the patients had Wolff-Parkinson-White syndrome. Overall, $30 \%$ had congenital heart disease. More than half of the infants received abortive therapy including adenosine. Acute therapy was used in $40 \%$ infants. In $70 \%$ of the patients, adenosine was used as abortive treatment Acute treatment was used for $40 \%$ of the patients. The most commonly used (75\%) drug in acute therapy was amiodarone followed by esmolol. Secondary prevention therapy was used in $\% 70$ of the infants. The most commonly used agents were beta-blockers, (57\%) followed by sotalol (43\%).

Conclusion: Cardiac arrhytmias are among the important causes of morbidity in infants. If not diagnosed, and treated it is a serious cause of mortality in infants. The physicians should be alert about etiologies, development, and natural course of arrrhytmias during fetal, and neonatal periods.
\end{abstract}

Keywords: Neonatal supraventricular tachycardia, beta-blockers, adverse event

\section{öz}

Amaç: Neonatal aritmiler yenidoğan döneminde ortaya çıkan anormal kalp hızı olarak tanımlanır. Çeşitli kardiyovasküler, sistemik ve metabolik hastalıkların bir sonucu olarak ortaya çıkabilirler. Yenidoğanlarda supraventriküler taşikardi (SVT) en sık görülen aritmidir. Biz bu çalışmada SVT tedavisinde kullanılan tedavi yöntemlerinin etkinlik ve güvenilirliğini araştırmayı amaçladık

Yöntem: Çalışmada, Aralık-2016 ve Aralık-2017 tarihleri arasında Izmir Buca Kadın Doğum ve Çocuk Hastanesi Yenidoğan Yoğun Bakım Ünitesi'ne SVT tanısıyla yatırılarak tedavi edilen hastaların dosyası retrospektif olarak incelenmiştir.

Bulgular: SVT tanısı alan 10 hasta mevcuttu. Altta yatan hastalıklar incelendiğinde \%80 hasta non spesifik SVT olarak değerlendirilirken \%20 hastada Wolff-Parkinson-White sendromu mevcuttu. Tüm hastaların \%30'unda konjenital kalp hastalığı mevcuttu. Hastaların \%70'ine abortif tedavi olarak adenozin kullanıldı. Akut terapi hastaların \%40'ına uygulandı. Akut terapide en sık kullanılan ilaç amirodaron idi (\%75), bunu esmolol (\%25) takip. Sekonder önleyici tedavi hastaların \%70'ine uygulandı. En sık kullanılan ajan beta blokör (\%57) onu takiben sotalol (\%43) idi.

Sonuç: Kardiyak aritmiler, bebek morbiditesinin önemli nedenlerinden biridir. Teşhis ve tedavi edilmezse ciddi bir bebek ölüm nedenidir. Hekimlerin fetal ve neonatal dönemde aritmilerin etyolojisi, gelişimi ve doğal seyri hakkında dikkatli olması önemlidir.

Anahtar kelimeler: Yenidoğan supraventriküler taşikardi, beta blokörler, yan etki
A. Şimşek 0000-0001-6387-4926 Sağlık Bakanlığı İzmir Buca Kadın Doğum ve Çocuk Hastanesi, Çocuk Kardiyolojisi Bölümü, İzmir, Türkiye

Cite as: Baysal B, şimşek A. Yenidoğan supraventriküler taşikardi vaka serisi: Farklı tedavilerin ve klinik sonuçların değerlendirilmesi. Tepecik Eğit. ve Araşt. Hast. Dergisi. rilmesi. Tepecik Eğit.
(C) Telif hakkı TC. Să̆lkk Bakanlı̆̆ı İzmir Tepecik Eğit. ve Arast. Hastanesi. Logos Tip Yayınclık tarafindan yayınlanmaktadır. Bu dergide yayınlanan bütün makaleler Creative Commons Atf-GayriTicari 4.0 Uluslararası Lisansı ile lisanslanmıştr.

(c) Copyright Association of Publication of the T.C. Ministry of Health Izmir Tepecik Education and Research Hospital. This journal published by Logos Medical Publishing.

Licenced by Creative Commons Attribution-NonCommercial 4.0 International (CC BY) 
INTRODUCTION

Supraventricular tachycardia (SVT) is a common pediatric condition affecting 1:250 to 1:1000 infants and children ${ }^{(1)}$. The incidence of neonatal arrhythmias was reported to be $0.4 \%$ and $0.7 \%$ in 2 different studies from our country. The frequency of SVT among these patients was $57.1 \%$ and $30.0 \%{ }^{(2,3)}$. SVT shows spontaneous regression in many newborns in the first year of life.

SVT is a generic term for an accelerated, non sinüs rhythm originating above the level of the AV junction with a rate of 200 to $300 \mathrm{bpm}{ }^{(4)}$. SVT may originate from an anatomical focus or may be of electrophysiological origin. In normal conditions, the passage of rapid atrial contractions to the ventricles is prevented on the AV node. Failure of this delay with reentry mechanism causes SVT ${ }^{(5)}$.

In general, pharmacological treatment is sufficient for suppression of SVT until spontaneous regression occurs ${ }^{(6,7)}$. Drugs in the treatment of SVT are classified as abortive therapies, acute treatment therapies and secondary prevention therapies ${ }^{\left({ }^{8}\right)}$. The epidemiology and the intervention needs of pediatric patients with SVT remain unclear ${ }^{(9)}$.

In this study, we aimed to evaluate the treatment and the side effects of common medications used in the treatment of SVT.

\section{MATERIALS and METHODS}

This study included 10 neonates who received medical therapy for SVT at NICU department of Buca Obstetric, Gynecology and Pediatrics Hospital in Izmir between December 2016 and December 2017. Information aboult the demographic characteristics of the infants were obtained from their electronic medical charts. Permission for this study was granted by Dokuz Eylül University Ethics Committee and the Turkish Public Health Institution (2019/01-15,
18.01.2019).

Diagnosis was performed with 12-lead ECG (ECG) based on the presence of a heart rate of 180 or above, absence of a $p$ wave in the ECG, and a narrow QRS interval (4). Cardiac structures and ventricular functions were evaluated by echocardiography. Efficacy was defined as absence of any clinical tachycardia detected on ECG. at outpatient follow-up examinations.

We classified newborns by presence of any congenital heart disease other than patent ductus arteriosus. The need of inotropic agents and invasive mechanical ventilation during the use of antiarrhythmic drugs was recorded ${ }^{(8)}$. Arrhythmias were categorized as Wolff-Parkinson-White syndrome or unspecified SVT ${ }^{(4)}$.

The abortive therapy is described as cardioversion or adenosine used at any time. Acute therapy is defined as treatment with esmolol or amiodarone if started on the first day of diagnosis. Secondary prevention therapy is defined as esmolol or amiodarone if started after the first day of diagnosis, or sotalol, digoxin or beta-blocker if started any time after establishment of diagnosis. Recurrence of SVT is defined as SVT observed after the first day of diagnosis ${ }^{(8)}$.

We assessed the adverse events (AEs) due to medications used in STV treatment including hypotension, bradycardia, hyperkalemia, hypoglycemia, bronchospasm and hypothyroidism.

Descriptive statistics were generated for the demographic, clinical, and medication variables and then tested for differences between the two age groups using Pearson's Chi-square, Fisher's exact test, or the Wilcoxon rank-sum test where appropriate. We used the Statistical Package for Social Sciences (SPSS, version 15.0, SPSS Inc., Chicago, IL, USA) for analysis with findings of $p<0.05$ considered as statistically significant. 


\section{RESULTS}

In our study, atotal of 1668 newborns were treated in the tertiary neonatal intensive care unit for one year period. The frequency of SVT in our unit was $\% 0.05$. The mean gestational age was 37.6 weeks and birth weight of the infants was $2850 \mathrm{~g}$. The mean postnatal age at diagnosis was 8.9 days, and $40 \%$ were diagnosed with SVT in the first week of their lives. Unspecified SVT (80\%) and Wolff-ParkinsonWhite syndrome $(20 \%)$ were seen in indicated percentage of patients (Table 1). Overall, $30 \%$ had CHD and all of them were atrial septal defect. No patient required inotropic or respiratory support.

Table 1. Patient characteristics, $\mathrm{n}$ (\%).

\begin{tabular}{|c|c|c|c|}
\hline & $\begin{array}{c}\text { No CHD } \\
\mathrm{N}=7\end{array}$ & $\begin{array}{l}\mathrm{CHD} \\
\mathrm{N}=3\end{array}$ & $\begin{array}{c}\text { Overall } \\
N=10\end{array}$ \\
\hline \multicolumn{4}{|c|}{ Gestational age, weeks } \\
\hline$<32$ & 1 (14) & $0(0)$ & $1(10)$ \\
\hline $32-36$ & $5(72)$ & $2(66)$ & $7(70)$ \\
\hline$\geq 37$ & $1(14)$ & $1(34)$ & $2(20)$ \\
\hline \multicolumn{4}{|l|}{ Birth weight, gr } \\
\hline $1500-2500$ & $3(42)$ & & $3(30)$ \\
\hline $2500-3500$ & & $3(100)$ & $3(30)$ \\
\hline$\geq 3500$ & $4(58)$ & $0(0)$ & $4(40)$ \\
\hline \multicolumn{4}{|c|}{ Postnatal ages, days } \\
\hline$<7$ & $2(28)$ & $2(66)$ & $4(40)$ \\
\hline 7-14 & $4(57)$ & $1(34)$ & $5(50)$ \\
\hline$\geq 14$ & $1(15)$ & & $1(10)$ \\
\hline \multicolumn{4}{|l|}{ Type of SVT } \\
\hline Unspecified SVT & $6(85)$ & $2(66)$ & $8(80)$ \\
\hline WPW syndrome & $1(15)$ & $1(34)$ & $2(20)$ \\
\hline
\end{tabular}

Adenosine was administered to approximately half of the cases as abortive therapy (7/10, 70\%). No cardioversion was required. Abortive therapy was not statistically significant in infants without CHD. Acute

Table 2. Type of SVT Therapy, $\mathrm{n}(\%)$.

\begin{tabular}{lccc}
\hline & $\begin{array}{c}\text { No CHD } \\
\mathbf{N = 7}\end{array}$ & $\begin{array}{c}\text { CHD } \\
\mathbf{N = 3}\end{array}$ & $\begin{array}{c}\text { Overall } \\
\mathbf{N = 1 0}\end{array}$ \\
\hline Hospitalisation duration* & $5.7 \pm 2.1$ & $7.6 \pm 0.6$ & $6.3 \pm 2.0$ \\
Abortive therapy & $4(57)$ & $3(100)$ & $7(70)$ \\
Adenosine & $4(57)$ & $3(100)$ & $7(70)$ \\
Acute therapy & $2(28)$ & $3(100)$ & $5(50)$ \\
Amiodarone & $1(14)$ & $3(100)$ & $4(40)$ \\
Esmolol & $1(14)$ & & $1(10)$ \\
Secondary prevention therapy & $4(57)$ & $3(100)$ & $7(70)$ \\
Beta-blocker & $1(14)$ & $3(100)$ & $4(40)$ \\
Sotalol & $3(43)$ & & $3(30)$ \\
& & & \\
\hline
\end{tabular}

*Values are expressed as mean $( \pm S d),{ }^{* *} p<0.05$ therapy was performed in $40 \%$ of infants. Amiodarone was the most common acute treatment agent (75\%) followed by esmolol (25\%). Secondary prevention therapy were used for $70 \%$ of infants. Propranolol was the most commonly used drug (57\%), followed by sotalol (43\%) (Table 2 ).

No mortality was determined. Patients with CHD were not hospitalised for relatively longer duration. In $20 \%$ of the infants recurrence of SVT required adenosine beyond the first day of treatment Adverse events occurred in one infant while on acute therapy. One patient diagnosed as acute bronchiolitis and SVT secondary to salbutamol therapy had bronchospasm after administration of esmolol therapy. Bradycardia, hypoglycemia or hyperkalemia was not detected during or after the therapy.

\section{DISCUSSION}

In our study adenosine was the most commonly used drug in abortive therapy. Antiarrhythmic treatments are planned empirically according to individual experiences and observational studies. In literature we found wide range of medications have been used in the treatment of SVT. Adenosine is most commonly used abortive therapy in SVT except atrial flutter where cardioversion is preferred. Adenosine acts by inhibiting cyclic adenosine monophosphate and by regulating calcium flow and increasing potassium conduction which prevents AV nodal conduction and leads to an extension of the AV nodal refractory period ${ }^{(10)}$.

In our study amiodarone was the most commonly used agent in acute treatment followed by esmolol. Amiodarone is III class antiarrhythmic drug. Amiodarone prolongs the duration of action potential and allows the cardiac cells to remain in the refractory phase ${ }^{(7)}$. Bolat et al. ${ }^{(11)}$ published a case report showing the effect of amiodarone in the treatment of resistant SVT. Resistance to SVT treatment and recurrence of SVT are more common in patients with 
CHD. Also these patients are hemodynamically instable and generally require acute therapy. In previous studies, digoxin was most commonly used mediacation in acute treatment because of its negative inotropic effect and easily measurable blood level (12). But also digoxin has a hypotensive effect and patients receiving digoxin treatment often require multiple drugs ${ }^{(13)}$.

Our study have demonstrated that beta-blockers have replaced digoxin as the preferred drug in secondary prevention therapy. Digoxin and beta-blockers are the first-line drugs for secondary prevention of SVT. A recent study revealed that use of propranolol for the neonates with SVT has been associated with lower mortality and hospital costs compared with digoxin ${ }^{(14)}$.

There was no significant difference between the duration of hospitalization in patients of SVT with and without CHD. On contrary Karmegeraj et al. ${ }^{(15)}$ revealed that hospital stay was longer in patients with CHD. Similar to previous studies ASD was the most common CHD in our study ${ }^{(16)}$. In our study there was no mortality due to SVT. Similar to our study a multicentre study had revealed no mortality in infants diagnosed with SVT ${ }^{(17)}$. This demonstrates the importance of early detection and treatment of SVT.

In our study there was a bronchospasm and impairment of circulation after esmolol therapy. We did not find bradycardia, hyperkalemia and hypoglycemia. Retrospective studies are not sufficient to evaluate the adverse effects. However, it is important to assess the efficacy and safety of the drugs used in SVT treatment. Hypotension and hypothyroidism are known side effects of amiodarone ${ }^{(18)}$. In addition, the possibility of bronchospasm increases with the use of esmolol ${ }^{(15)}$. This shows that we need to know the side effect spectrum of each drug to be used in the treatment.
The main limitation of the study was the limited number of patients. The reliability of the statistical results was affected due to the low number of patients. The absence of follow-up documents of patients after discharge was another limitation.

\section{CONCLUSION}

The medications used in treatment are selected according to clinical observations. Side effects should be kept in mind as well as the benefits of the drugs used. In this study, we tried to present our clinical observation in the treatment of SVT. Nevertheless, we think that there is a lack of a universal guide in the treatment of SVT. Future prospective clinical studies will be able to contribute to the literature in this direction.

Ethics Committee Approval: Dokuz Eylül University Non-Interventional Research Ethics Committee approval was obtained (2019/01-15).

Conflict of Interest: We have no conflict of interest. Funding: There was no funding needed for this research.

Informed Consent: Receipt.

\section{REFERENCES}

1. Weindling SN, Saul JP, Walsh EP. Efficacy and risks of medical therapy for supraventricular tachycardia in neonates and infants. Am Heart J. 1996;131:66-72. [CrossRef]

2. Satar M, Narlı N, Özbarlas N, Yıldıztaş HY. Yenidoğan döneminde aritmi gelişen 21 olgunun değerlendirilmesi. Çocuk Sağlığı ve Hastalıkları Dergisi. 2006;49:107-11.

3. Canpolat $\mathrm{E}$, Korkmaz A, Yurdakök $\mathrm{M}$ ve ark. Neonatal aritmiler: Yenidoğan yoğun bakım ünitesinde on yıllık deneyim. Çocuk Sağlığı ve Hastalıkları Dergisi. 2002;46:187-94.

4. Spearman AD, Williams P. Supraventricular tachycardia in infancy and childhood. Pediatr Ann. 2014;43(11):456-60. [CrossRef]

5. Ko JK, Deal BJ, Strasburger JF, Benson DW Jr. Supraventricular tachycardia mechanisms and their age distribution in pediatric patients. Am J Cardiol. 1992;69:1028-32. [CrossRef]

6. Wong KK, Potts JE, Etheridge SP, Sanatani S. Medications used to manage supraventricular tachycardia in the infant a North American survey. Pediatr Cardiol. 2006;27:199-203. [CrossRef]

7. Tavera MC, Bassareo PP, Neroni $P$ et al. Supraventricular tachycardia in neonates: antiarrhythmic drug choice dilemma. J Matern Fetal Neonatal Med. 2010;23(Suppl 3):30-3. 
[CrossRef]

8. Chu PY, Hill KD, Clark RH, Smith PB, Hornik CP. Treatment of supraventricular tachycardia in infants: Analysis of a large multicenterdatabase. Early Hum Dev. 2015;91(6):345-50. [CrossRef]

9. Clausen $\mathrm{H}$, Theophilos $\mathrm{T}$, Jackno K, Babl FE. Paediatric arrhythmias in the emergency department. Emerg Med J. 2012;29(9):732-7. [CrossRef]

10. Guerrier K, Shamszad P, Czosek RJ, Spar DS, Knilans TK, Anderson JB. Variation in Antiarrhythmic Management of Infants Hospitalized with Supraventricular Tachycardia: A Multi-Institutional Analysis. Pediatr Cardiol. 2016;37(5):94652. [CrossRef]

11. Bolat F, Uslu S, Cömert S, Dindar A, Bülbül A, Nuhoğlu A. Yenidoğanda Supraventriküler Taşikardi Vakası: Güncel Tedavi Yaklaşımı. Çocuk Dergisi. 2010;10(1):51-4. [CrossRef]

12. Sridharan S, Sullivan I, Tomek V et al. Flecainide versus digoxin for fetal supraventricular tachycardia: Comparison of two drug treatment protocols. Heart Rhythm. 2016;13(9):1913-9. [CrossRef]

13. Dilber E, Mutlu M, Dilber B, Aslan Y, Gedik Y, Celiker A. Intravenous amiodarone used alone or in combination with digoxin for life-threatening supraventricular tachyarrhythmia in neonates and small infants. Pediatr Emerg Care.
2010;26(2):82-4. [CrossRef]

14. Bolin EH, Lang SM, Tang X, Collins RT. Propranolol Versus Digoxin in the Neonate for Supraventricular Tachycardia (from the Pediatric Health Information System). Am J Cardiol. 2017;119(10):1605-10. [CrossRef]

15. Karmegeraj B, Namdeo S, Sudhakar A, Krishnan V, Kunjukutty $R$, Vaidyanathan $B$. Clinical presentation, management, and postnatal outcomes of fetal tachyarrhythmias: A 10-year single-center experience. Ann Pediatr Cardiol. 2018;11(1):34-9. [CrossRef]

16. Tortoriello TA, Snyder CS, Smith EO, Fenrich AL Jr, Friedman RA, Kertesz NJ. Frequency of recurrence among infants with supraventricular tachycardia and comparison of recurrence rates among those with and without preexcitation and among those with and without response to digoxin and/or propranolol therapy. Am J Cardiol. 2003;92(9):1045-9. [CrossRef]

17. Hoeffler CD, Krenek ME, Brand MC. Wolff-Parkinson-White Syndrome in a Term Infant Presenting With Cardiopulmonary Arrest. Adv Neonatal Care. 2016;16(1):44-51. [CrossRef]

18. Chang PM, Silka MJ, Moromisato DY, Bar-Cohen Y. Amiodarone versus procainamide for the acute treatment of recurrent supraventricular tachycardia in pediatric patients. Circ Arrhythm Electrophysiol. 2010;3(2):134-40. [CrossRef] 